DOI: $10.5455 / 2320-1770$. ijrcog20130626

Case Report

\title{
Pregnancy following re-stenosis of complete transverse vaginal septum
}

\author{
Alka Sehgal, Shikha Rani*, Navneet Takkar
}

Department of Obstetrics and Gynecology, Government Medical College and Hospital, Chandigarh, India

Received: 2 February 2013

Accepted: 10 March 2013

*Correspondence:

Dr. Shikha Rani,

E-mail: shikhataneja2000@yahoo.co.in

(C) 2013 Sehgal A et al. This is an open-access article distributed under the terms of the Creative Commons Attribution License, which permits unrestricted use, distribution, and reproduction in any medium, provided the original work is properly cited.

\section{ABSTRACT}

We report a case of 23 year woman who came to us with 6 weeks pregnancy and complete transverse vaginal septum. Cesarean section along with resection of septum was done. Restenosis of vagina was observed during puerperium. No surgical intervention was done. Spontaneous pregnancy with well- formed vagina was noted after 3 years.

Keywords: Vaginal septum, Pregnancy, Re-stenosis

\section{INTRODUCTION}

The incidence of transverse vaginal septum varies from 1:2100 to $1: 72000 .^{1}$ The vertical fusion or canalization disorder of Mullerian ducts and urogenital sinus result in partial or complete vaginal septum of various thickness $(0.5-6 \mathrm{~cm}) .^{2}$ Septum may be complete but usually has a laterally placed tiny hole giving an impression of vaginal vault without a cervix. Septum may be present in lower, middle and upper thirds in $19 \%, 35 \%$ and $46 \%$ of the patients respectively.

\section{CASE REPORT}

A young newly married woman came to us with 6 weeks of amenorrhoea. On examination the vagina was $4 \mathrm{~cm}$ deep and ending blindly, cervix could neither be seen nor felt. Pregnancy was confirmed on ultrasound, however, the thickness of the septum or length of non-canalized vagina could not be assessed accurately. At term examination under anesthesia revealed approximately $2 \mathrm{~cm}$ thick septum, with a very laterally placed tiny hole $(1 \mathrm{~mm})$ at 5 'clock position (Figure 1). In view of increased vascularity and anticipating soft tissue trauma during vaginal birth, caesarean section was performed. Intraoperatively no abnormality of urogenital system or any stigma of endometriosis was detected. Septum was excised for lochia drainage. The exposed cervix and the upper vagina appeared normal (Figure 2). Six week later patient had vaginal stenoses and cervix was only partially visualized. However, patient refused any further intervention as she was asymptomatic. Three years later patient came to us with a term uncomplicated second pregnancy with a well formed vagina. There was no history of any surgical intervention for vaginal septum after termination of first pregnancy at our hospital. She delivered her second child vaginally without complications.

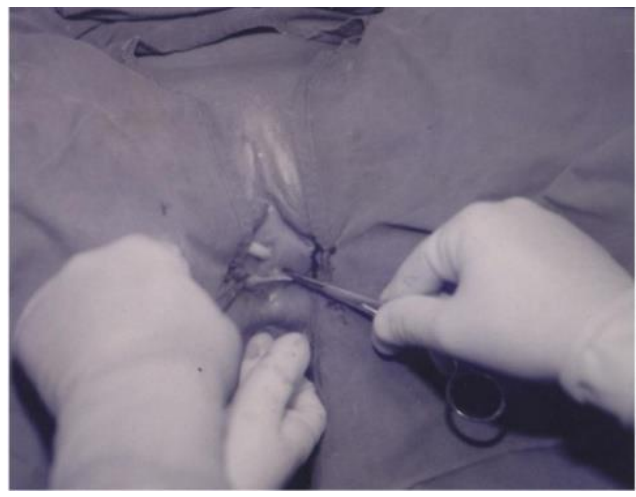

Figure 1: Complete transverse vaginal septum with a pin point hole. 


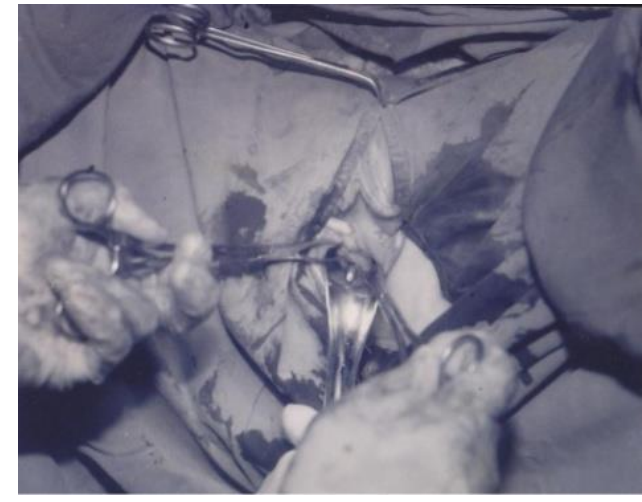

Figure 2: Excision of vaginal septum with cervix exposed.

\section{DISCUSSION}

Complete vaginal septum may present with dysmenorrhoea, dyspareunia or infertility in adult patients. In non-pregnant stage either manual dilatation of the micro-perforation or surgical excision of septa is done. Good success rates following surgery of complete transverse vaginal septum has been reported. ${ }^{3}$ However, restenosis is the most common post-operative complication. ${ }^{4}$ To prevent restenosis patient must wear a stent continuously for first 2 months after the surgery and at night for next 4 months. However, if stenosis occurs it may be treated with dilatation or surgery. ${ }^{4}$ Bautista et al reported a case of term pregnancy with complete transverse vaginal septum in which surgical correction was done in puerperium with no post- operative vaginal stenosis. ${ }^{5}$ Our patient developed restenosis but was asymptomatic with satisfactory coital functions. After post-operative stenosis patient had sexual relation which helped her to regain normal vaginal patency.
To conclude, manual dilation of post-operative stenosis should be advised in either asymptomatic patients or patients at high risk for surgery.

\section{Funding: None \\ Competing interests: None declared \\ Ethical approval: Not required}

\section{REFERENCES}

1. Rock JA, Lesley LB. Surgery for anomalies of the mullerian ducts. In: Rock JA, Jones HW, Te Linde RWTLsog, eds. Te Linde's operative gynecology. 10th ed. ed. Philadelphia, Pa.; London: Lippincott Williams \& Wilkins 2008:539-84.

2. Tindall VR. Malformations \& rnaldevlopment of genital tract. In: Jeffcoate $\mathrm{N}$, Tindall VR, eds. Jeffcoate's principles of gynaecology. 5th ed. London: Butterworth 1997:135-58.

3. Rock JA, Zacur HA, Dlugi AM, Jones HW, Jr., TeLinde RW. Pregnancy success following surgical correction of imperforate hymen and complete transverse vaginal septum. Obstet Gynecol 1982;59:448-51.

4. Quint EH, McCarthy JD, Smith YR. Vaginal surgery for congenital anomalies. Clin Obstet Gynecol 2010;53:115-24.

5. Bautista Gomez E, Morales-Garcia V, FloresRomero AL, Pizarro Osorno N, Velasquez-Valdivia A. Transverse vaginal septum in the upper part of the vagina and pregnancy. Ginecol Obstet Mex 2012;80:487-90.

DOI: $10.5455 / 2320-1770 . i j r \operatorname{cog} 20130626$

Cite this article as: Sehgal A, Rani S, Takkar N. Pregnancy following re-stenosis of complete transverse vaginal septum. Int J Reprod Contracept Obstet Gynecol 2013;2:229-30. 